\title{
Plankton diversity and limnological characterization in two shallow tropical urban reservoirs of Pernambuco State, Brazil
}

\author{
VIVIANE L.S. ALMEIDA ${ }^{1}$, MARIA DA GRAÇA G. MELÃO ${ }^{2}$ and ARIADNE N. MOURA ${ }^{3}$ \\ ${ }^{1}$ Centro de Ciências Biológicas e da Saúde, Programa de Pós-Graduação em Ecologia e Recursos Naturais, \\ Universidade Federal de São Carlos (UFSCar), Rod. Washington Luís, Km 235, 13565-905 São Carlos, SP, Brasil \\ ${ }^{2}$ Centro de Ciências Biológicas e da Saúde, Departamento de Hidrobiologia, Universidade Federal de São Carlos (UFSCar), \\ Rod. Washington Luís, Km 235, 13565-905 São Carlos, SP, Brasil \\ ${ }^{3}$ Departamento de Biologia, Programa de Pós-Graduação em Botânica, Universidade Federal Rural de Pernambuco (UFRPE), \\ Av. Dom Manoel de Medeiros, s/n, Dois Irmãos, 52171-900 Recife, PE, Brasil
}

Manuscript received on January 24, 2011; accepted for publication on December 2, 2011

\begin{abstract}
Plankton diversity, physical and chemical variables and chlorophyll $a$ were analyzed in two shallow urban reservoirs with different trophic degrees on Pernambuco State, northeastern Brazil. High eutrophication levels were observed in Apipucos reservoir, while Prata reservoir was considered oligotrophic. Values reported for physical and chemical variables and chlorophyll $a$ differed among the studied ecosystems. Richness and plankton diversity were higher in Apipucos reservoir especially for phytoplankton. The presence of potential toxic Cyanophyceae in both reservoirs reflects a problem mainly to Prata reservoir, which is used for public water supply. Differences were observed for some variables among sites of study in Apipucos reservoir, while the differences among strata were negligible in both reservoirs, reflecting the water column mixing by wind action. Rainfall regulated the temporal dynamics for the analyzed variables, with significant seasonal differences, mainly for the major of limnological variables in Apipucos reservoir. Plankton diversity was higher in Apipucos reservoir, especially to phytoplankton, showing that eutrophication and pollution can favor plankton diversity in tropical urban shallow reservoirs.
\end{abstract}

Key words: northeastern Brazil, phytoplankton, trophic status, zooplankton.

\section{INTRODUCTION}

The success of ecological studies in reservoirs depends on the evaluation of diversity, structure and dynamics of biological communities (Tundisi and MatsumuraTundisi 2008), allied to physical and chemical characterization, since the interactions among these variables are directly linked to processes and patterns in freshwater reservoirs (Straskraba and Tundisi 2000).

Correspondence to: Viviane Lúcia dos Santos Almeida

E-mail: vlsa.almeida@bol.com.br
Plankton communities exhibit an essential role in biomass production and energy transfer in aquatic environments by including organisms of different trophic levels, from the base (phytoplankton) to consumers of high levels (zooplankton) of food web (Almeida et al. 2010).

In freshwater, phytoplankton includes organisms from several groups, like Cyanophyta, Bacillariophyta, Chlorophyta and Euglenophyta, among others (Moura et al. 2007). Concerning the zooplankton in reservoirs, this community is composed mainly by Rotifera and 
Crustacea (Cladocera and Copepoda); however, other organisms may appear in zooplankton samples, such as some species of Protists, Turbellaria and Insecta, which should be listed as occasional fauna and not as true plankton once they belong predominantly to benthic or periphytic habitats (Pennak 1978, Almeida et al. 2010).

Plankton communities in each environment depend on adaptations to biotic and abiotic characteristics, including the trophic status, which is directly related to the diversity, abundance and distribution of plankton forms in the reservoirs (Galkovskaya and Mityanina 2005). Changes in reservoirs' trophic status can cause serious damages to the system, especially when eutrophication occurs (Smith et al. 2006), since this process interferes in the ecological balance and leads to changes in limnological (such as abrupt $\mathrm{pH}$ oscillation and increased toxic gases concentration) and biological (e.g. changes in organisms diversity) conditions (Khan and Ansari 2005).

In the shallow lakes, despite the little volume of water per area, a complex of factors regulates the aquatic dynamics, which are represented in tropical regions especially by the rain and radiation (Talling 2001). Aquatic vegetation has also a great importance in the shallow lakes by acting in ecological processes (Moss 1998). However, the knowledge on shallow tropical reservoirs is still scarce, mainly in the northeastern Brazil, where there are few published studies in these kinds of systems.

Thus, in the present work, the limnological and planktonic community characterization was performed in two shallow urban reservoirs with different trophic conditions, during a full hidrological cycle, in order to evaluate the influences of the nutritional status over the plankton diversity in such tropical environments. Our hypothesis is that plankton diversity differs among aquatic systems characterized by different nutritional conditions, being reduced in eutrophic reservoirs with high pollution input.

\section{MATERIALS AND METHODS}

STUDY AREA

This study was conducted in two shallow tropical urban reservoirs from Pernambuco State, northeastern Brazil, which are small and geographically closed (about $4 \mathrm{~km}$ far from each other). These water bodies comprise the main river basin in Pernambuco (Capibaribe) and differ on the use, surrounding area occupation, human impacts and water nutritional status. The regional hydrological cycle is characterized by a rainy (March to August) and a dry (September to February) season.

Prata reservoir is an oligotrophic ecosystem located at $08^{\circ} 00^{\prime} 28.5^{\prime \prime} \mathrm{S}$ and $34^{\circ} 50^{\prime} 54.5^{\prime \prime} \mathrm{W}$, with about $18,550 \mathrm{~m}^{2}, 35,962 \mathrm{~m}^{3}$ of average volume and depth between 0.15 and $4.40 \mathrm{~m}$. The clear water is used as a supply. The abundance of emergent and submerged macrophytes is great, represented mainly by the genera Eleocharis and Cabomba. The surround area is formed by remainders of rain forest vegetation with no direct anthropogenic impacts being observed in this water body.

Apipucos reservoir is located at $8^{\circ} 01$ ' 14 " $\mathrm{S}$ and $34^{\circ} 56^{\prime} 00^{\prime \prime} \mathrm{W}$, with $2.9 \mathrm{~km}^{2}$ of area, 556,375 $\mathrm{m}^{3}$ of average volume and $2.5 \mathrm{~m}$ of average depth (Neumann-Leitão et al. 1989). It has been built for floods containment and recreation, consisting of two interconnected subsystems. The occurrence of freefloating macrophytes is expressive, represented mainly by Eichhornia crassipes (Mart.). For its historical, cultural and environmental values, this water body is considered an "Environmental Protection Area". However, the organic (untreated sewage release) and chemical (commercial and industrial effluents) pollution input is high, resulting in elevated eutrophication levels in this system.

SAMPLING STRATEGY AND LABORATORY ANALYSES

Water sampling was carried out monthly from March, 2008 to February, 2009, always between 08:30 and 
11:00h, using a 10-liter container and a 5 L Van Dorn bottle. All samples were obtained in duplicate.

In Prata reservoir one point of study was established. In Apipucos reservoir, two points of study were chosen, each one representing a reservoir' subsystem; point $1(\mathrm{P} 1)$ was located in the pelagic region and point $2(\mathrm{P} 2)$ in the littoral region. Samples were taken in surface and bottom layers, with the exception of P2 in Apipucos reservoir whose reduced depth limited water sampling to the surface layer. Climatological data were obtained from the ID 32568 Recife Station, Center for Weather Forecasting and Climate Studies, National Institute for Space Research, whose coverage includes both reservoirs. Data on physical and chemical variables of water were measured in situ using portable probes, except for $\mathrm{pH}$, which was determined by a bench pot analyses in laboratory within three hours after sampling.

The euphotic zone extent was calculated by multiplying the Secchi disc's transparency value by the factor 2.7 (Esteves 1998). Chlorophyll $a$ concentrations and the suspended solids were determined by Lawton et al. (1999) and the gravimetric method, respectively. Protocols proposed by Valderrama (1981) and Strickland and Parsons (1965) were used for phosphatic nutrients analysis. The trophic status was determined through the monthly average of surface chlorophyll $a$ and total phosphorus values (Carlson 1977 modified by Toledo Jr 1990).

Phytoplankton was analyzed from a total of $100 \mathrm{~mL}$-samples preserved with acetic Lugol under refrigeration. Subsamples were observed in $10 \mathrm{~mL}-$ chambers using an inverted microscope Zeiss Axiovert 135M under 400x magnification after 24 hours of sedimentation (Utermöhl 1958) through counting in random fields (Uhelinger 1964).

50 to $100 \mathrm{~L}$ and 20 to $40 \mathrm{~L}$ of water from Prata and Apipucos reservoirs were filtered through a 68 $\mu \mathrm{m}$ mesh net to collect the zooplankton. Samples were preserved with $4 \%$ formalin added to $6 \%$ glucose after organisms had been anesthetized with carbonated water. The analysis was performed under light Coleman microscopy model N200-T, SedgwickRafter chamber with $2 \mathrm{~mL}$ capacity and 100x magnification. The accompanying fauna, formed by occasional plankton taxa, was also described.

Specialized literature was used for the taxonomic classification of planktonic organisms. The occurrence frequency of taxa was determined according to Dajoz (1983). Diversity (Shannon 1948) and evenness (Pielou 1977) indices were calculated from total density data. Parametric (Tukey) and non-parametric (MannWhitney) tests were used to evaluate the differences in values found for variables that were analyzed concerning seasonality, sites and depths studied; differences were considered significant when $\mathrm{p}<0.05$.

\section{RESULTS}

Climatological And LimnOlogical VARIABLeS

For rainfall, mean values recorded during rainy $(273.67 \mathrm{~mm})$ and dry $(97.22 \mathrm{~mm})$ seasons were significantly different (Tukey: $p=0.003$ ), while for other climatological variables no seasonal difference was detected. The air temperature ranged between 18 and $33^{\circ} \mathrm{C}$, with $26.3^{\circ} \mathrm{C}$ average. The annual average values for relative humidity and wind speed were $78.3 \%$ and $4.6 \mathrm{~m} \mathrm{~s}^{-1}$, respectively. For water's abiotic variables and chlorophyll $a$, the data summary is showed in Table I.

In Prata reservoir, the difference between both seasons was significant for depth (Tukey: $\mathrm{p}=0.007$ ), water temperature (Tukey: $\mathrm{p}=0.001$ ), dissolved oxygen concentration (Tukey: $p=0.003$ ) and electrical conductivity (Tukey: $p=0.000$ ), with the higher values being reported in the dry season. For turbidity, $\mathrm{pH}$, total suspended solids, phosphate nutrients and chlorophyll $a$, seasonal differences were not significant, as observed for vertical variations of all described variables. The inorganic matter has always represented the majority of suspended solids, except for the bottom stratum in January. 


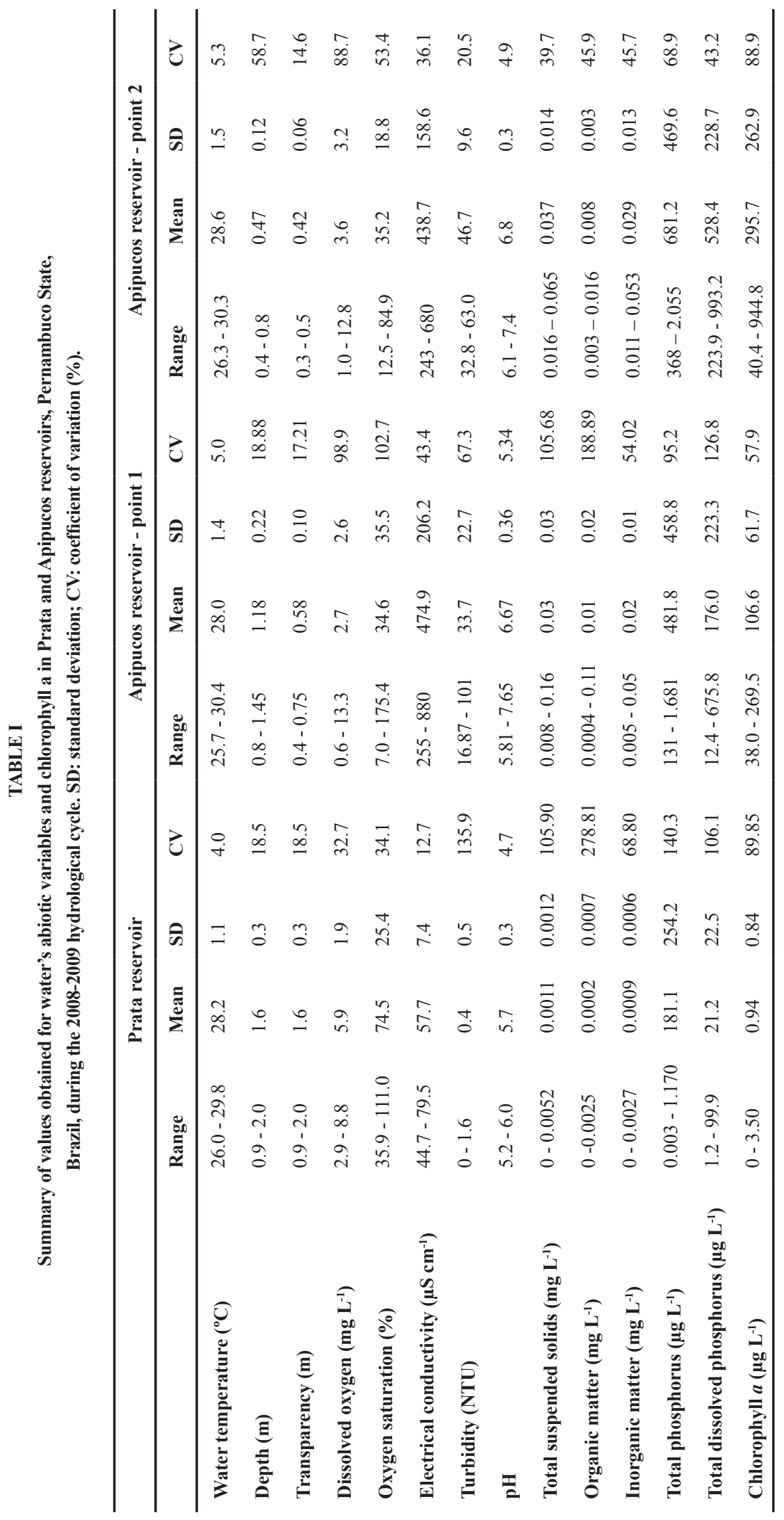


In Apipucos reservoir, depth and transparency were lower at P2 compared to P1. The euphotic zone has always represented the entire water column. The annual average for water temperature was $28.4^{\circ} \mathrm{C}$ considering both study points, with no significant seasonal or spatial differences. For dissolved oxygen concentration $\left(3.16 \mathrm{mg} \mathrm{L}^{-1}\right.$ annual average, $34.9 \%$ saturation), higher levels were observed during the dry season in both P1 (Tukey: $\mathrm{p}=0.0006)$ and P2 (Mann-Whitney: $\mathrm{p}=0.0247$ ), and for the surface in relation to the bottom at $\mathrm{P} 1$ (Tukey: $\mathrm{p}=0.0308$ ).

For conductivity, higher values were recorded during the dry season in both points (MannWhitney: $p=0.000$ in P1 and Tukey: $p=0.005$ in $\mathrm{P} 2)$. Average values of turbidity were significantly higher in P2 (Mann-Whitney: $p=0.009$ ), especially during the rainy season (Tukey: $p=0.013$ ).

The water $\mathrm{pH}$ ranged from acidic to neutral with little temporal and spatial oscillation. Values for total suspended solids in P1 were higher in the bottom stratum (Mann-Whitney: $p=0.020$ ) and in the average for the dry season in both points as well (Mann-Whitney: $p=0.003$, Tukey: $p=0.003$ ).
Inorganic matter was higher than the organic one during the entire water cycle in both study points.

Total phosphorus (TP) (Tukey: $p=0.032$ ) and total dissolved phosphorus (PTD) (Mann-Whitney: $\mathrm{p}=0.001)$ values were significantly higher at P2. In $\mathrm{P} 1$, the values were significantly higher in the rainy season when compared with the dry season (MannWhitney: $\mathrm{p}=0.037$ for PT and $\mathrm{p}=0.007$ for PTD). For chlorophyll $a$, the average value recorded in P2 was twice that obtained in P1 (Mann-Whitney: $\mathrm{p}=0.014$ ), and higher values were observed during the dry season in both points (Tukey: $p=0.009$ for $\mathrm{P} 1$ and $\mathrm{p}=0.003$ for $\mathrm{P} 2$ ).

\section{TROPHIC STATUS}

According to annual average values for the trophic status index (TSI), Prata reservoir was considered oligotrophic. However, the classification between mesotrophic and eutrophic was observed in some months due to the influence of total phosphorus (TP). Values found for the chlorophyll $a$ index differed from those obtained for the TP index in this reservoir (Table II).

TABLE II

Monthly values and classification by the Trophic Status Index (TSI) of waters in Prata and Apipucos reservoirs, Pernambuco State, Brazil, during the 2008-2009 hydrological cycle. TP: total phosphorus; CL: chlorophyll a; P1: point 1; P2: point 2; olig: oligotrophic; mes: mesotrophic; eut: eutrophic; hip: hypertrophic.

\begin{tabular}{|c|c|c|c|c|c|c|c|c|c|c|c|c|c|c|}
\hline & & Mar & Apr & May & Jun & Jul & Aug & Sep & Oct & Nov & Dec & Jan & Feb & Mean \\
\hline \multirow{4}{*}{ 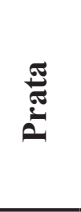 } & TSI (TP) & 0.00 & 21.2 & 82.4 & 78.1 & 54.9 & 53.8 & 47.5 & 48.7 & 66.9 & 70.3 & 69.9 & 67.7 & 47.9 \\
\hline & TSI (CL) & 34.7 & 40.8 & 35.8 & 22.9 & 32.3 & 0.0 & 0.0 & 25.3 & 32.3 & 29.4 & 29.4 & 29.4 & 26.0 \\
\hline & TSI (mean) & 0.00 & 31.0 & 59.1 & 50.5 & 43.6 & 26.9 & 23.8 & 37.0 & 49.6 & 49.8 & 49.6 & 48.5 & 36.9 \\
\hline & Category & olig & olig & eut & mes & olig & olig & olig & olig & mes & mes & mes & mes & olig \\
\hline \multirow{4}{*}{ 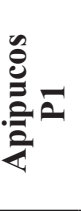 } & TSI (TP) & 86.8 & 92.4 & 103.3 & 97.6 & 73.0 & 70.9 & 71.9 & 76.5 & 67.1 & 71.6 & 75.4 & 79.0 & 80.5 \\
\hline & TSI (CL) & 79.4 & 68.1 & 71.9 & 68.8 & 75.4 & 67.1 & 82.6 & 70.2 & 77.8 & 86.7 & 77.2 & 76.7 & 75.2 \\
\hline & TSI (mean) & 83.1 & 80.3 & 87.6 & 83.2 & 74.2 & 69.0 & 77.3 & 73.3 & 72.4 & 79.1 & 76.3 & 77.9 & 77.8 \\
\hline & Category & hip & hip & hip & hip & hip & eut & hip & eut & eut & hip & hip & hip & hip \\
\hline \multirow{4}{*}{ 造 } & TSI (PT) & 90.8 & 97.1 & 106.8 & 82.0 & 85.7 & 86.4 & 88.8 & 89.5 & 83.9 & 82.7 & 88.2 & 85.2 & 88.9 \\
\hline & TSI (CL) & 80.9 & 76.2 & 69.9 & 67.7 & 84.6 & 81.0 & 81.7 & 87.6 & 92.2 & 99.3 & 93.9 & 91.0 & 83.8 \\
\hline & TSI (mean) & 85.9 & 86.6 & 88.4 & 74.8 & 85.2 & 83.7 & 85.2 & 88.6 & 88.0 & 91.0 & 91.1 & 88.1 & 86.4 \\
\hline & Category & hip & hip & hip & hip & hip & hip & hip & hip & hip & hip & hip & hip & hip \\
\hline
\end{tabular}


In Apipucos reservoir, values regarding chlorophyll $a$ and TP indices were very similar, and classified this water body as eutrophic to hypertrophic during the entire water cycle, with the higher values for TSI in P2 (Table II).
RICHNESS, COMPOSITION AND DIVERSITY OF PLANKTONIC COMMUNITIES

Phytoplankton community was composed by 57 species. The richness was higher in the Apipucos (46 spp.) than in Prata reservoir (31 spp.). Chlorophyta

TABLE III

Taxonomic composition and occurrence frequency of phytoplankton in Prata and Apipucos reservoirs, Pernambuco State, Brazil, during the 2008-2009 hydrological cycle. P1: point 1, P2: point 2 ; + : sporadic or infrequent; ++ : frequent, +++ : very frequent.

\begin{tabular}{|c|c|c|c|}
\hline \multirow{2}{*}{ Taxa } & \multicolumn{3}{|c|}{ Occurrence Frequency } \\
\hline & Prata & Apipucos P1 & Apipucos P2 \\
\hline \multicolumn{4}{|l|}{ Cyanophyta } \\
\hline Aphanocapsa sp. & - & + & + \\
\hline Dolichospermum sp. & + & - & - \\
\hline Geitlerinema amphibium (C. Agardh) Anagnostidis & ++ & - & - \\
\hline Lyngbya sp. 1 & + & - & - \\
\hline Lyngbya sp. 2 & ++ & - & - \\
\hline Merismopedia sp. & + & +++ & +++ \\
\hline Oscillatoria sp. & - & + & ++ \\
\hline Romeria sp. & - & + & + \\
\hline \multicolumn{4}{|l|}{ Bacillariophyta } \\
\hline Amphipleura sp. & ++ & - & - \\
\hline Anomoeoneis serians (Brébisson) Cleve & + & - & - \\
\hline Aulacoseira granulata (Ehrenberg) Simosen & + & +++ & +++ \\
\hline Cyclotella meneghiniana Kützing & + & ++ & ++ \\
\hline Gomphonema sp. & + & - & - \\
\hline Melosira distans (Ehrenberg) Kützing & + & +++ & +++ \\
\hline Nitzschia palea (Kützing) W. Smith & - & + & - \\
\hline Pinnularia SP. & + & + & - \\
\hline Ulnaria ulna (Nitzsch) P. Compère & - & + & + \\
\hline \multicolumn{4}{|l|}{ Chlorophyta } \\
\hline Actinastrum gracillimum Smith & - & + & + \\
\hline Actinastrum hantzschii Lagerheim & - & + & +++ \\
\hline Ankistrodesmus gracilis (Reinsch) Korshikov & - & + & + \\
\hline Closterium acutum Brébisson & + & + & + \\
\hline Coelastrum microporum Nägeli & - & + & ++ \\
\hline Cosmarium sp. & ++ & + & - \\
\hline Crucigenia tetrapedia (Kirchner) W. West and G. S. West & - & ++ & + \\
\hline Desmodesmus denticulatus (Lagerheim) Na., Frield and Hegewald & - & + & ++ \\
\hline Desmodesmus protuberans (Fritsch and Rich) E.Hegewald & + & ++ & + \\
\hline Desmodesmus quadricauda (Turpin) Hegewald & + & +++ & +++ \\
\hline Golenkinia paucispina West and West & - & + & + \\
\hline Kirchneriella obesa (W. West) Schmidle & - & +++ & ++ \\
\hline Micractinium pusillum Frenesius & - & ++ & ++ \\
\hline Monoraphidium arcuatum (Korshikov) Hindák & - & ++ & ++ \\
\hline Monoraphidium contortum (Thuret) Komárková-Legnerová & + & + & ++ \\
\hline Monoraphidium griffithii (Berkeley) Komárková-Legnerová & + & +++ & +++ \\
\hline Pediastrum duplex Meyen & + & ++ & ++ \\
\hline Pediastrum tetras (Ehrenberg) Ralfs & - & + & + \\
\hline Scenedesmus acuminatus (Lagerheim) Chodat & + & +++ & +++ \\
\hline
\end{tabular}


TABLE III (continuation)

\begin{tabular}{|c|c|c|c|}
\hline \multirow{2}{*}{ Taxa } & \multicolumn{3}{|c|}{ Occurrence Frequency } \\
\hline & Prata & Apipucos P1 & Apipucos P2 \\
\hline Scenedesmus acutus Meyen & - & + & - \\
\hline Scenedesmus bicaudatus (Hansgirg) Chodat & + & +++ & ++ \\
\hline Scenedesmus bijugus (Turpin) Kützing & + & +++ & +++ \\
\hline Schroederia setigera (Schröder) Lemmermann & - & + & - \\
\hline Staurastrum SP. & - & + & - \\
\hline Tetmemorus laevis (Kützing) Ralfs & + & - & - \\
\hline Tetraedron incus (Teiling) G.M. Smith & + & - & - \\
\hline Tetraedron minimum (A. Braun) Hansgirg & - & + & + \\
\hline Tetraedron trigonum (Nägeli) Hansgirg & + & ++ & ++ \\
\hline Tetrastrum elegans Playfair & + & + & + \\
\hline \multicolumn{4}{|l|}{ Chrysophyta } \\
\hline Dinobryon sp. & + & - & - \\
\hline \multicolumn{4}{|l|}{ Euglenophyta } \\
\hline Cryptomonas sp. & + & - & - \\
\hline Euglena acus Ehrenberg & - & - & + \\
\hline Euglena SP. & ++ & +++ & ++ \\
\hline Lepocinclis ovum (Ehrenberg) Lemermann & - & + & + \\
\hline Mallomonas SP. & - & + & + \\
\hline Phacus acuminatus Stokes & - & + & - \\
\hline Phacus curvicauda Svirenko & - & + & + \\
\hline Phacus tortus (Lemmermann) Skvortsov & - & + & + \\
\hline Trachelomonas volvocina Ehrenberg & + & +++ & +++ \\
\hline \multicolumn{4}{|l|}{ Dinophyta } \\
\hline Peridinium sp. & +++ & + & + \\
\hline Richness & 31 & 45 & 39 \\
\hline
\end{tabular}
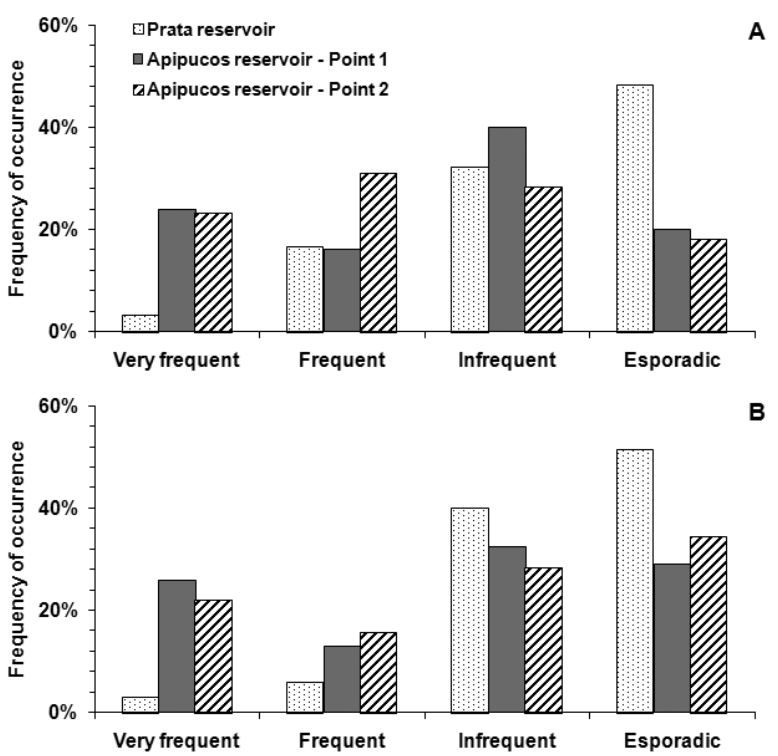

Figure 1. Phytoplankton (A) and zooplankton (B) frequencies of occurrence of taxa in the Prata and Apipucos reservoirs, Pernambuco State, Brazil, during the 2008-2009 hydrological cycle. Very frequent: $>70 \%$ frequent: $70 \%$; $-40 \%$; infrequent: $40 \%+10 \%$; sporadic: $<10 \%$. was dominat in number of species in both reservoirs, represented mainly by the genus Scenedesmus and followed by Bacillariophyta in Prata and Bacillariophyta and Euglenophyta in Apipucos (Table III).

Most phytoplankton taxa $(80.7 \%)$ was considered infrequent or sporadic in Prata reservoir, while for Apipucos reservoir the ratio of these categories of organisms was lower $(60.0 \%$ in $\mathrm{P} 1$ and $46.6 \%$ in P2) (Figure 1A).

The average diversity in Prata reservoir was 2.07 bits ind ${ }^{-1}$, less than the values obtained in Apipucos reservoir (3.32 bits ind ${ }^{-1}$ at $\mathrm{P} 1$ and 2.46 bits ind $^{-1}$ at $\mathrm{P} 2)$. Concerning evenness, the mean values recorded in Prata (0.76) and Apipucos reservoir P1 (0.80) were quite similar, while in Apipucos reservoir P2 the values were lower (mean 0.59). Differences among Apipucos reservoir's points were significant for both diversity and evenness (Mann-Whitney: $\mathrm{p}=0.000$ ). 
TABLE IV

Taxonomic composition and occurrence frequency of zooplankton in Prata and Apipucos reservoirs during the 2008-2009 hydrological cycle. P1: point 1, P2: point 2; cf.: to be confirmed; +: sporadic or infrequent; + +: frequent, +++ : very frequent.

\begin{tabular}{|c|c|c|c|}
\hline \multirow{2}{*}{ Taxa } & \multicolumn{3}{|c|}{ Occurrence Frequency } \\
\hline & Prata & Apipucos P1 & Apipucos P2 \\
\hline \multicolumn{4}{|l|}{ Rotifera } \\
\hline Anuraeopsis fissa (Gosse, 1851) & + & + & + \\
\hline Asplanchna priodonta Gosse, 1850 & - & +++ & +++ \\
\hline Asplanchnopus hyalinus Harring, 1913 & + & + & + \\
\hline Brachionus angularis Gosse, 1851 & + & +++ & +++ \\
\hline Brachionus calyciflorus anuraeiformis (Brehm, 1909) & - & + & ++ \\
\hline Brachionus calyciflorus calyciflorus Pallas, 1766 & + & +++ & ++ \\
\hline Brachionus caudatus Barrois and Daday, 1894 & + & +++ & +++ \\
\hline Brachionus falcatus Zacharias, 1898 & + & +++ & +++ \\
\hline Brachionus havanaensis Rousselet, 1911 & + & + & - \\
\hline Brachionus quadridentatus (Hermann, 1783) & + & + & + \\
\hline Brachionus rubens Ehrenberg, 1838 & + & + & + \\
\hline Cephalodella sp. & + & + & + \\
\hline Conochilus dossuarius (Hudson, 1885) & - & ++ & ++ \\
\hline Conochilus unicornis Rousselet, 1892 & - & + & + \\
\hline Epiphanes macrouros (Barrois and Daday, 1894) & - & ++ & ++ \\
\hline Filinia longiseta (Ehrenberg, 1834) & + & ++ & +++ \\
\hline Kellicottia sp. & + & - & - \\
\hline Keratella tropica (Apstein, 1907) & + & +++ & ++ \\
\hline Lecane (Monostyla) bulla (Gosse, 1886) & + & - & + \\
\hline Lecane (Monostyla) curvicornis (Murray, 1913) & + & - & + \\
\hline Lecane (Monostyla) leontina (Turner, 1892) & + & - & - \\
\hline Lecane (Monostyla) luna (O. F. Muller, 1776) & + & + & + \\
\hline Lecane (Monostyla) lunaris (Ehrenberg, 1832) & + & - & - \\
\hline Lecane (Monostyla) papuana (Murray, 1913) & + & - & + \\
\hline Lecane sp. & + & - & + \\
\hline Lepadella patella (O. F. Müller, 1786) & - & + & + \\
\hline Macrochaetus collinsi (Gosse, 1867) & + & - & - \\
\hline Platyias quadricornis (Ehrenberg, 1832) & + & + & + \\
\hline Ploesoma truncatum (Levander, 1894) & - & + & + \\
\hline Polyarthra vulgaris (Carlin, 1943) & + & +++ & + \\
\hline Rotaria rotatoria (Pallas, 1766) & - & + & + \\
\hline Rotaria sp. & + & + & + \\
\hline Testudinella patina (Hermann, 1783) & + & + & + \\
\hline Trichocerca sp. & - & + & - \\
\hline \multicolumn{4}{|l|}{ Cladocera } \\
\hline Biapertura sp. cf. & - & + & - \\
\hline Dadaya macrops (Daday, 1898) & + & - & + \\
\hline Diaphanosoma spinulosum Herbst, 1967 & + & + & + \\
\hline Disparalona dadayi (Birge, 1910) & +++ & + & - \\
\hline Moina micrura (Kurz, 1874) & + & ++ & +++ \\
\hline \multicolumn{4}{|l|}{ Copepoda } \\
\hline Notodiaptomus cearensis Wright, 1936 (adult) & ++ & + & + \\
\hline Copepodit of $N$. cearensis & + & + & - \\
\hline Nauplii of $N$. cearensis & + & + & + \\
\hline Thermocyclops decipiens Kiefer, 1927 (adult) & ++ & ++ & +++ \\
\hline Copepodit of $T$. decipiens & + & ++ & + \\
\hline Nauplii of T. decipiens & + & +++ & +++ \\
\hline Richness & 35 & 36 & 35 \\
\hline
\end{tabular}


For zooplankton, a total of 45 taxa was recorded in this study, with the higher richness in Apipucos (40 spp.) compared to Prata reservoir (35 spp.). Considering each point of study in Apipucos reservoir, the numbers of taxa was similar. Rotifera showed the highest richness compared to Crustacea (Table IV), which was represented mainly by the genera Lecane (in the Prata reservoir) and Brachionus (in Prata and Apipucos reservoirs).

Most of the zooplankton taxa $(91.4 \%)$ was classified as sporadic or infrequent in the Prata reservoir, the same occurring in Apipucos reservoir, but in smaller proportions $(61.3 \%$ at $\mathrm{P} 1$ and $62.5 \%$ at P2) (Figure 1B). Rotifera and Copepoda occurred throughout the hydrologic cycle in both reservoirs, in contrast to Cladocera, which was absent in several samples, mainly at P2 in the Apipucos reservoir.

The average values of zooplankton diversity were lower in Prata reservoir (1.83 bits ind $\left.{ }^{-1}\right)$ compared to those found in Apipucos reservoir (2.43 and 2.44 bits ind $^{-1}$ at points 1 and 2, respectively). However, average evenness values were higher in Prata reservoir (0.80) compared to those found at points $1(0.70)$ and $2(0.69)$ in Apipucos reservoir. No seasonal or vertical differences were observed for diversity values in both reservoirs; however, the average equitability values in Prata reservoir differed significantly (Tukey: $p=0.002$ ) between rainy (0.71) and dry (0.90) seasons.

The accompanying fauna consisted of Alveolata (Arcella vulgaris Ehrenberg, 1830; Ballanium sp.; Centropyxis acureata (Ehrenberg, 1838); Didinium sp.; Difflugia sp. and Vorticella sp.), nematodes, mites, ostracods and insects (larvae and adults). Eleven taxa occurred in Prata reservoir, of which nine were also present in Apipucos reservoir. Centropyxis acureata (in both reservoirs), Difflugia sp. and Nematoda (in Prata reservoir) were the most frequent taxa. It is highlighted that individuals of Ostracoda and Nematoda, usually benthic organisms, were also found in surface samples in Prata reservoir.

\section{DISCUSSION}

In Apipucos reservoir, the similar values of trophic status determined by chlorophyll $a$ and total phosphorus indices show the stability of the eutrophication process in this water body since, according to Moraes (2001), total phosphorus acts as a causative agent of the process, while chlorophyll $a$ is considered a response resulted from algal growth. On the other hand Prata reservoir, although being regarded as meso- to eutrophic in some months, presented chlorophyll $a$ index values lower than those determined by the total phosphorus index, confirming the oligotrophic conditions of its waters.

Oligotrophic conditions in Prata reservoir caused greater transparency and higher dissolved oxygen concentrations, while in Apipucos reservoir, an eutrophic system in which phosphate nutrients are abundant, high values of conductivity, turbidity, total solids and chlorophyll $a$ were observed, particularly at $\mathrm{P} 2$.

According to Garcés (1984), dissolved oxygen concentrations in Prata reservoir is probably adequate for biota development in contrast to Apipucos reservoir, since aerobic communities require concentrations above $4 \mathrm{mg} \mathrm{L}^{-1}$. It is suggested that macrophytes are among the factors directly related to oxygen dynamics in both reservoirs.

Submerged macrophytes are important components of reservoirs' metabolism, absorbing carbon dioxide through photosynthesis (Desmet et al. 2008) and serving as refuge for aquatic organisms (Genkai-Kato 2007). Concerning floating macrophytes, their development can cause problems by disease vectors dispersion (Kengne et al. 2003) and reduction in the oxygen levels by decomposition (Bianchini Jr et al. 2008).

High temperature and intense solar radiation favored the growth of macrophytes in tropical ecosystems (Camargo and Esteves 1995). Depending on the amount of plant detritus, decomposition may contribute to water nutrient enrichment and raise 
the oxygen demands for the oxidation of carbon and freeing of nutrients (Bianchini Jr et al. 2008).

High values for suspended solids (SS) in Apipucos reservoir must be related to low water transparency in this water body since, according to Malmaeus and Hakanson (2003), SS have an influence in the Secchi disc depth. In relation to SS types, Wetzel (1993) stated that the predominance of inorganic carbon is common in aquatic ecosystems.

Biogenic turbidity, phosphate nutrients, chlorophyll $a$ and conductivity are descriptive variables of eutrophication (Moraes 2001). Thus, higher values of these variables at P2 compared to P1 indicate a greater input or accumulation of pollution at this point in Apipucos reservoir.

For $\mathrm{pH}$, the values were acid during the whole hydrological cycle in Prata reservoir, and the same occurs at some months in Apipucos reservoir. This result seems to be associated with the predominance of organic acids from decomposing macrophytes (Lima and Kobayashi 1988). According to Moss (1998), low $\mathrm{pH}$ values affects the aquatic biota development, can lead to decline in productivity and may intensify eutrophication impacts by the solubilization of toxic elements.

Rainfall regulated temporal dynamics, leading to significant seasonal differences for several limnological variables especially in Apipucos reservoir. Rainfall is a key factor in the hydrological dynamics in northeastern Brazil, a region characterized by high temperatures and hydrological irregularity throughout the year.

The values for the most variables were significantly higher in the dry season, especially those related to eutrophication in Apipucos reservoir (see Table II). This fact should be related to increased temperatures, macrophytes abundance and higher rates of organic matter decomposition. On the other hand, concentrations of phosphate nutrients were higher in the rainy season in this reservoir, showing the rain influence in carrying loads of allochthonous nutrients.
In contrast to seasonal differences, vertical homogeneity was detected for limnological variables in both reservoirs, except for dissolved oxygen concentrations and suspended solids in Apipucos reservoir. This homogeneity reflects the water column mix caused by the wind action, which is strong for the shallow systems (Moss 1998).

The euphotic zone extended throughout the water column, allowing light to reach the sediment in both reservoirs. According to Wetzel (1993), tropical shallow lakes receive high incidence of solar radiation, and the euphotic zone can extend along the entire water column. This fact explains the similar values among vertical strata for chlorophyll $a$ in Apipucos reservoir since there are no light restrictions for photosynthesis and phytoplankton may develop in the entire water column.

A higher richness for planktonic communities was observed in the eutrophic Apipucos reservoir, with a greater difference in the number of taxa for phytoplankton compared to zooplankton between both studied ecosystems. These results contrast with those described by some authors (eg. Wetzel 1993, Pompeo 1999). According to Pompeo (1999), the biota may have high species richness, but reduced density of organisms in oligotrophic lakes. In contrast, regarding eutrophic water bodies, adverse conditions for most biota favor the presence of reduced number of tolerant species, which generally develop large population densities (Tundisi and Matsumura-Tundisi 2008).

However, Pinto-Coelho et al. (1999) observed that while phytoplankton richness increases with eutrophication, zooplankton showed an analogous richness in Pampulha reservoir, similar to the results found in the present work. According to MatsumuraTundisi and Tundisi (2005), high plankton richness in eutrophic reservoirs is explained by "intermediate disturbance hypothesis", in which horizontal gradients and vertical instability positively affect the planktonic richness and density, in spite of the eutrophication process. 
The higher Chlorophyta richness observed in this study is common in continental waters of Brazil (Moura et al. 2007). This algal division was represented mostly by colonial organisms such as Desmodesmus, Pediastrum and Scenedesmus, the latter being the most diverse one.

Scenedesmus is a common and cosmopolitan genus of green algae that inhabits waters with different nutritional conditions (Bicudo and Menezes 2006), occurring especially in shallow mixing reservoirs characterized by elevated organic matter input and low water transparency (Reynolds et al. 2002, Padisák et al. 2009).

Despite the low richness for Cyanophyceae in both reservoirs, we emphasize the occurrence of potential toxic taxa among this group, like Geitlerinema amphibium, Lyngbya spp. and Oscillatoria sp. The presence of these taxa represents a problem due to their capacity to release toxins in the water, which may cause serious damages to human health (Calijuri et al. 2006).

High temperatures, neutral to alkaline $\mathrm{pH}$ conditions, and elevated nutrient concentrations (Azevedo 1998), as observed in Apipucos reservoir, favored the development of Cyanophyceae species. However, the presence of these organisms is a greater problem in Prata reservoir that despite the low nutritional status that limited algal growth, is used for public supply, which requires the monitoring of potential toxic Cyanophyceae density to avoid health problems in the population.

Concerning zooplankton, higher Rotifera richness is usually recorded in the Brazilian reservoirs (Neumann-Leitão et al. 1989). Rotifers may occur in lakes with different trophic conditions (Matsumura-Tundisi and Tundisi 2005) and almost always dominate in eutrophic environments (Pontin e Langley 1993, Nogueira 2001). Specifically in shallow systems, these organisms can be favored by environmental disturbances, such as the reduction in dissolved oxygen concentrations (Berzins and Pejler 1989).
The genus Brachionus is important to the zooplankton biodiversity in tropical freshwaters and represents most of the Rotifera richness in several water bodies (Almeida et al. 2006). The occurrence of Brachionus calyciflorus anuraeiformis only for Apipucos reservoir shows the deterioration in water conditions by pollution (Neumann-Leitão et al. 1989) since this subespecies indicates low values for dissolved oxygen and high nutrient input.

Differences in the sporadic/infrequent taxa ratio between both studied reservoirs reflect the influence of the trophic status in plankton composition, with a higher population variation in oligotrophic systems and the frequent presence of tolerant species in eutrophic environments throughout the hydrological cycle.

Lower values for diversity were recorded in the Prata reservoir for both planktonic communities compared to Apipucos, corroborating the results found by Pinto-Coelho et al. (1999) in Pampulha reservoir. As observed in the present study, these authors detected a lower evenness for phytoplankton under more eutrophic conditions, while there was a minor variation for zooplankton.

In Apipucos reservoir point 2, lower values of diversity and evenness for both planktonic communities compared to point 1 were not expected, since this point is located in the littoral zone. According to Dajoz (1983), the littoral zone of reservoirs shows more ecological niches and consequently higher biological diversity compared to the pelagic zone. Thus, we suggested that the deterioration of water quality at this point of study is a limiting factor to the occurrence of certain species, which consequently reduces the diversity.

Regarding the accompanying fauna, the occurrence of Ostracoda and Nematoda in the superficial layer of the water column in the Prata reservoir confirms the influence of winds in mixing events of water column in this environment, since these organisms normally inhabit lacustrine sediments. 
Concerning our hypothesis, the results confirmed that the nutritional status of aquatic systems influenced plankton diversity. However, in contrast to what we expected, the plankton diversity was higher in Apipucos reservoir, especially to phytoplankton, showing that eutrophication and pollution can favor plankton diversity in tropical urban shallow reservoirs as explained by the hypothesis of intermediate disturbance.

However, despite the increase of diversity, high eutrophication levels reflect the excess of nutrient discharges in urban water bodies caused mainly by the drift from marginal areas and domestic/industrial wastes (Carpenter et al. 1998). This enrichment leads to problems such as blooms of toxic algae, reduced oxygen and fish death, degrading the water quality and harming its uses by pollution. Although waters in Apipucos reservoir have not being used for drinking, it is important to maintain its minimal quality to ensure the ecological and social services of this natural resource.

\section{ACKNOWLEDGMENTS}

The authors wish to thank to the Microalgae Taxonomy and Ecology Laboratory (Rural Federal University of Pernambuco) team, for their help in field works and support in laboratory procedures. VLSA would like to thank Conselho Nacional de Desenvolvimento Científico e Tecnológico (CNPq) for financial support during her $\mathrm{PhD}$.

\section{RESUMO}

Diversidade planctônica, variáveis físicas e químicas e clorofila $a$ foram analisadas em dois reservatórios urbanos rasos com diferentes graus de trofia, no estado de Pernambuco, nordeste do Brasil. Elevados níveis de eutrofização foram observados no reservatório de Apipucos, enquanto o reservatório do Prata foi considerado oligotrófico. Os valores registrados para as variáveis físicas e químicas e clorofila $a$ diferiram entre os ecossistemas estudados. Riqueza e diversidade planctônicas foram mais elevadas no reservatório de Apipucos, principalmente para o fitoplâncton. A presença de cianobactérias potencialmente tóxicas em ambos os reservatórios reflete um problema, principalmente no reservatório do Prata, o qual é utilizado para abastecimento público. Diferenças espaciais foram observadas para algumas variáveis entre os pontos de estudo no reservatório de Apipucos, enquanto as diferenças entre as profundidades foram negligenciáveis em ambos os reservatórios, refletindo a mistura da coluna d'água pela ação do vento. A precipitação pluviométrica regulou a dinâmica temporal das variáveis analisadas, com diferenças sazonais significativas, principalmente para a maioria das variáveis limnológicas no reservatório de Apipucos. A diversidade planctônica foi maior no reservatório de Apipucos, revelando que a eutrofização e a poluição podem favorecer a diversidade planctônica em reservatórios tropicais urbanos rasos.

Palavras-chave: nordeste do Brasil, fitoplâncton, estado trófico, zooplâncton.

\section{REFERENCES}

Almeida VlS, LARRAZÁBAL MEL, MOURA AN AND MELO-JÚNIOR M. 2006. Rotifera das zonas limnética e litorânea do reservatório de Tapacurá, Pernambuco, Brasil. Iheringia Ser Zool 96(4): 445-451.

Almeida Vls, Melo-Júnior M, Paranaguá MN, LARrAzÁBAL MEL AND MELÃo MGG. 2010. O zooplâncton de água doce e seu estudo em reservatórios do Nordeste do Brasil. In: MOURA AN, ARAÚJO EL, BITTENCOURT-OLIVEIRA MC, PIMENTEL RMM AND ALBUQUERQUE UP (Eds), Reservatórios do Nordeste do Brasil: biodiversidade, ecologia e manejo, Bauru: Canal6, Bauru, Brasil, p. 441-475.

AzEVEdo SMFO. 1998. Toxinas de Cianobactérias: causas e consequências para a saúde pública. Med on line 1(3).

BERZINS B AND PEJLER B. 1989. Rotifer occurrence in relation to oxygen content. Hydrobiologia 183: 165-172.

BIANCHINI JR I, CUNHA-SANTINO MB AND PERET AM. 2008. Oxygen demand during mineralization of aquatic macrophytes from an oxbow lake. Braz J Biol 68(1): 61-67. 
Bicudo CEM AND Menezes M. 2006. Gêneros de algas de águas continentais do Brasil: chave para identificação e descrições, $2^{a}$ ed., São Carlos: Rima, 489 p.

CAlijuri MC, Alves MAS AND Dos SAntos ACA. 2006. Cianobactérias e cianotoxinas em águas continentais, São Carlos: Rima, 118 p.

CAMARgo AFM AND Esteves FA. 1995. Biomass and productivity of aquatic macrophytes in Brazilian lacustrine ecosystems. In: TUNDISI JG, BICUDO CEM AND MATSUMURA-TUNDISI T (Eds), Limnology in Brazil, Rio de Janeiro: ABC e SBL, Rio de Janeiro, Brazil, p. 137-149.

CARLSON RE. 1977. A trophic state index for lakes. Limnol Oceanogr 22: 361-369.

Carpenter SR, Caraco NF, Correll DL, Howarth RW, SHARPLEY AN AND SMITH VH. 1998. Nonpoint pollution of surface waters with phosphorus and nitrogen. Ecol Appl 8: 559-568.

DAJOZ R. 1983. Ecologia Geral. Petrópolis: Vozes, 472 p.

Desmet NJS, Van Belleghem S, Seuntjens P, Bouma TJ, BUIS K AND MEIRE P. 2008. Quantification of the impact of macrophytes on oxygen dynamics and nitrogen retention in a vegetated lowland river. Phys Chem Earth 36(12): 479-489.

EsteVes FA. 1998. Fundamentos de Limnologia, $2^{\text {a }}$ ed., Rio de Janeiro: Interciência, 602 p.

GALKOVSKAYA GA AND MitYANINA IF. 2005. Structure distinctions of pelagic rotifer plankton in stratified lakes with different human impact. Hydrobiologia 546: 387-395.

GARCÉS BHA. 1984. Estudio Preliminar sobre el zooplâncton Del lago Bayano, Panamá. Rev Biol Trop 32(1): 17-24.

GenKaI-Kato M. 2007. Macrophyte refuges, prey behavior and trophic interactions: consequences for lake water clarity. Ecol Lett 10: 105-114.

Kengne IM, Brissaud F, AKoA A, EtemeA RA, NyAA J, NDIKEFor A AND FonKou T. 2003. Mosquito development in a macrophyte-based wastewater treatment plant in Cameroon (Central Africa). Ecol Eng 21: 53-61.

KHAN FA AND ANSARI AA. 2005. Eutrophication: an ecological vision. The Bot Rev 71(4): 449-482.

LaWton L, Marsalek B, Padisák J And Chorus I. 1999. Determination of Cyanobacteria in the laboratory. In: CHORUS IAND BARTRAM J (Eds), Toxic Cyanobacteria in Water: a guide to their public health consequences, monitoring and management, London: World Health Organization, Routledge, London, England, p. 347-367.

LIMA WN AND KoBAYASHI CN. 1988. Sobre o quimismo predominante nas águas do sistema flúvio-estuarino de Barcena (PA). Geoch Bras 2: 53-71.

Malmaeus JM AND HaKAnson L. 2003. A dynamic model to predict suspended particulate matter in lakes. Ecol Model 167: $247-262$
MATSUMURA-TUNDISI T AND TUNDISI JG. 2005. Plankton richness in a eutrophic reservoir (Barra Bonita Reservoir, SP, Brazil). Hydrobiologia 542: 367-378.

Moraes AJ. 2001. Manual para avaliação da qualidade da água, São Carlos: Rima, 45 p.

Moss B. 1998. Ecology of fresh waters: man and medium, past to future, $3^{\text {rd }}$ ed., London: Blackwell Science, $557 \mathrm{p}$.

Moura AN, Wocyli-Dantas Ê AND BittencourtOLIVEIRA MC. 2007. Structure of the Phytoplankton in a Water Supply System in the State of Pernambuco - Brazil. Braz Arch Biol Technol 50(4): 645-654.

Neumann-Leitão S, NogueIra-Paranhos JD AND SouZA FBVA. 1989. Zooplâncton do açude de Apipucos, Recife PE (Brasil). Arq Biol Tecnol 32(4): 803-821.

NoGUEIRA MG. 2001. Zooplankton composition, dominance and abundance as indicators of environmental compartimentalization in Jurumim reservoir (Paranapanema river), São Paulo, Brazil. Hydrobiologia 455: 1-18.

PAdisÁk J, Crossetti LO AND NASElli-Flores L. 2009. Use and misuse in the application of the phytoplankton functional classification: a critical review with updates. Hydrobiologia 621: 1-19.

PENNAK RW. 1978. Freshwater invertebrates of the United States, $2^{\text {nd }}$ ed., New York: J Wiley \& Sons, 803 p.

PIELOU EC. 1977. Mathematical Ecology. $2^{\text {nd }}$ ed., New York: J Wiley \& Sons, 385 p.

PinTo-COElHo RM, COELHO MM, EsPÍRITO-SANTO MM AND CORNELISSEN TG. 1999. Efeitos da eutrofização na estrutura da comunidade planctônica na lagoa da Pampulha. In: HENRY R (Ed), Ecologia de reservatórios: estrutura, função e aspectos sociais, Botucatu: Fundibio/Fapesp, Botucatu, Brasil, p. 551-572.

POMPEO MLM. 1999. As macrófitas aquáticas em reservatórios tropicais: aspectos ecológicos e propostas de monitoramento e manejo. In: POMPEO MLM (Ed), Perspectivas da Limnologia no Brasil, São Luís: Gráfica e Editora União, São Luís, Brasil, p. 105-119.

Pontin RM AND LANGLEY JM. 1993. The user of rotifer ommunities to provide a preliminary national classification of small water bodies in England. Hydrobiologia 255/256: 411-419.

REYNOLDS CS, HusZAR V, KRUK C, NASELli-Flores L AND MELO S. 2002. Towards a functional classification of the freshwater phytoplankton. J Plankton Res 24(5): 417-428.

SHANNON CE. 1948. A mathematical theory of communication. Bell Syst Tech J 27: 379-423.

SMith VH, Joye SB AND Howarth RW. 2006. Eutrophication of freshwater and marine ecosystems. Limnol Oceanogr 51(1, part 2): 351-355.

Straskraba M AND TUNDISI JG. 2000. Diretrizes para o gerenciamento de lagos. Volume 9: gerenciamento da qualidade da água de represas, São Carlos: ILEC/IEE, 258 p. 
STRICKLAND JD AND PARSONS TR. 1965. A manual of sea water analysis. Bull J Fish Res Board Can 125: 1-185.

TALLING JF. 2001. Environmental controls on the functioning of shallow tropical lakes. Hydrobiologia 458: 1-8.

TOLEDO JR JAP. 1990. Informe preliminar sobre os estudos para obtenção de um índice do estado trófico de reservatórios de regiões quentes tropicais. Governo do Estado de São Paulo, Companhia de Tecnologia de Saneamento Ambiental, 1990. Internal report.

TUNDISI JG AND MATSUMURA-TUNDISI T. 2008. Limnologia, São Paulo: Oficina de Textos, 631 p.
UHELINGER V. 1964. Étude statistique des méthodes de dénombrement planctonique. Arch Sci 17: 121-223.

UTERMÖHL H. 1958. Zur Vervollkommnung der quantitativen Phytoplankton-Methodik. Mitteilungen Internationale Vereiningung fuer Theoretische und Angewandte. Limnologie 9: 1-38.

VALDERRAMA GC. 1981. The simultaneous analysis of total nitrogen and total phosphorus in natural waters. Mar Chem 10: 109-122.

Wetzel RG. 1993. Limnologia, Lisboa: Fundação Calouste Gulbenkian, 919 p. 